\title{
COMPARISON OF NEWTONIAN AND FOURIER THERMAL ANALYSIS TECHNIQUES FOR CALCULATION OF LATENT HEAT AND SOLID FRACTION OF ALUMINUM ALLOYS
}

\section{IZRAČUNAVANJE LATENTNE TOPLOTE I UDELA ČVRSTE FAZE TOKOM OČVRŠĆAVANJA LEGURA ALUMINIJUMA PRIMENOM NEWTONIAN I FOURIER JEDNAČINE NA KRIVE HLAĐENJA}

\author{
DARYOUSH EMADI*, LAURENCE V. WHITING*, MILE DJURDJEVIC**, \\ WITOLD T. KIERKUS**, JERRY SOKOLOWSKI** \\ *Materials Technology Laboratory - CANMET, 568 Booth Street, Ottawa, ON, Canada K1A \\ 0G1, demadi@NRCan.gc.ca, **NSERC/Ford-Nemak/University of Windsor Industrial Research \\ Chair in Light Metals Casting Technology, Mechanical, Automotive and Materials Engineering, \\ University of Windsor, Essex Hall, 401 Sunset Ave., Windsor, ON, Canada, N9B 3P4 \\ Primljeno: 16.01. 2004.
}

\begin{abstract}
The cooling curve analysis (CCA) has been used extensively in the metal casting industry, usually to predict alloy composition and microstructure constituents. The use of CCA can be expanded to other areas of solidification if the zero curves can be properly calculated. In this paper the Newtonian and Fourier techniques of zero curve determination are described. These techniques were developed to calculate latent heat and to determine the correlations between solid fraction and temperature/time for Al-7 $\mathrm{wt} \% \mathrm{Si}$ alloy. The importance of the changes in heat capacity and density of solid and liquid phases during solidification on the latent heat calculations was examined. The latent heat calculated by Computer-Aided Cooling Curve Analysis (CA-CCA) method is compared with those reported in the literature. The effect of experimental procedure and type of sampling cup on the latent heat calculations were studied for both techniques.
\end{abstract}

Key words: Thermal Analysis, Al-Si alloys, Newtonian and Fourier methods.

\section{ABSTRAKT}

Analiza krivih hladjenja je siroko primenjivana metoda u livnicama železnih i ne železnih metala/legura. U svakodnevnoj livačkoj praksi ova metoda je često korišćena za određivanje sastava legura i njihovih struktura. Primena ove metode može se znatno proširiti ukoliko bi se osnovna (nulta) linija ocvršćavanja legura matematicki tačno interpretirala. Newtonian i Fourier-ova metoda su opšte poznate metode za izračunavanje osnovnih/nultih linija krivih hlađenja. Obe metode su razvijene u cilju izračunavanja latentne toplote oslobođene tokom očvršćavanja čvrste faze različitih legura (u ovom radu su primenjene na leguri Al-7 wt.\% Si). Uticaji promene gustine i toplotnog kapaciteta čvrste $i$ tečne faze na izračunate vrednosti latentne toplote su analizirani u ovom radu. Izračunate vrednosti latentne toplote očvršćavanja su upoređene sa literaturnim podacima. $\mathrm{U}$ radu je takođe analiziran utical vrste tigla na eksperimentalno dobijene rezultate.

Ključne reči: Termijska Analiza, Al-Si legure, Newtonian adn Fourier metode. 


\section{INTRODUCTION}

A comprehensive understanding of melt quality is of paramount importance for the control and prediction of actual casting characteristics. If one is able to act in a proactive rather than a reactive manner in respect to melt and casting quality control, one can reduce cost downtime and scraps levels. Thermal (cooling curve) analysis can provide such capabilities and therefore has important advantages over its post-process counterparts, which are often destructive in nature.

Cooling curve analysis has been used for many years in fundamental metallurgical studies and for determining binary phase diagrams. The later is obtained by varying alloy composition, recording the arrest points during cooling, and then plotting the temperature-composition (phase) diagram. The cooling curve method is useful for commercial applications for a number of reasons: it is simple, inexpensive and provides consistent results. This technique is a good choice for drawing fundamental relationships between cooling curve characteristics, alloy composition and melt treatment.

The cooling curves can be analyzed by various methods [1-12]. Among these methods, Computer-Aided Cooling Curve Analysis (CA-CCA) is the most recent technique developed for cooling curve analysis (CCA). This technique is based on measuring the temperature change during solidification of molten metal poured in a small cup. The total latent heat and fraction solid can then be calculated by differentiating the cooling curve. There are different methods to analyze and mathematically derive these parameters from the cooling curve $[2,4,6,9,12]$. Traditional cooling curve analysis uses a wide variety of the sample cup sizes and cup materials, from sand, graphite, ceramics to stainless steel.

A critical requirement for the cooling curve analysis is determination of, what is called "the zero curve" or "the base line". The "zero curve" is in principle the first derivative of the cooling curve measured by the thermocouple(s), inserted in the alloy test sample, assuming that the metal doesn't undergo any phase transformation during the solidification process. In other words "the zero curve" overlaps the first derivative of the cooling curve in single phase parts of the sample cooling process, for $\mathrm{T}>\mathrm{T}$-liquidus and for $\mathrm{T}<$ T-solidus.

The Newtonian method of the CCA uses basically one thermocouple placed in the center of the test sample [5,9]. In some cases two thermocouples are used, placed on and off the center of the test sample, in order to provide an additional information about the solidification process [10]. Recently investigators have used two thermocouples and Fourier method to analyze the data and generate the zero curve $[2,4,12]$. Both procedures, Newtonian and Fourier, were used in this study to determine the latent heat and solid fraction formation history 
during the freezing of the $356(\mathrm{Al}-7 \mathrm{wt} \% \mathrm{Si})$ alloy. The Newtonian and Fourier analysis techniques for determination of the zero curves are briefly described below.

\section{Newtonian Analysis}

The Newtonian analysis of the metal solidification process is based on the following assumptions: (a) the cooling behaviour of the alloy test sample may be considered as "the lumped thermal system" where the Biot number is $<0.1$, (b) the sensible specific heat for the alloy can be considered as temperature independent and constant in the freezing temperature range, and (c) the heat transmission coefficient from the alloy test sample to its surrounding by convection, radiation and conduction can be characterized by the single unique temperature function for the given experimental conditions.

The heat balance equation for the solidifying sample-mould system can be written as $[3,9]$ :

$$
\frac{d Q}{d t}-M C_{P} \frac{d T}{d t}=U A\left(T-T_{0}\right)
$$

where, $\mathrm{M}$ is the mass of the sample, $\mathrm{C}_{\mathrm{P}}$ is specific heat of the metal, $\mathrm{T}$ is the metal temperature, $\mathrm{t}$ is time, $\mathrm{U}$ is overall heat transfer coefficient, $\mathrm{A}$ is sample surface area, $\mathrm{T}_{0}$ is ambient temperature, and $\mathrm{Q}$ is latent heat of solidification. If no phase transformation occurs, $d Q / d t=0$, then the cooling rate of the test sample (first derivative of the $\mathrm{CC}$ ) can be written as:

$$
\frac{d T}{d t}=-\frac{U A\left(T-T_{0}\right)}{M C_{P}}=Z_{N}
$$

The curve corresponding to Equation 2 represents the "Newtonian zero curve" or the baseline $\left(Z_{\mathrm{N}}\right)$. The analysis starts by fitting a polynomial, usually of the order of 3 or higher, to the first derivative of the cooling curve (CC) versus recorded temperature in the single phase portion of $\mathrm{CC}$ (for $\mathrm{T}>\mathrm{T}$ liquidus and $\mathrm{T}<\mathrm{T}$-solidus) (Figure 1). The total latent heat, $\mathrm{L}$, can be calculated from:

$$
L=\frac{Q}{M}=C_{P} \int_{t_{s}}^{t_{e}}\left[\left(\frac{d T}{d t}\right)_{c c}-Z_{N}\right] d t
$$

where $t_{s}$ and $t_{e}$ are the times for the start and end of solidification, and the subscripts $\mathrm{CC}$ for cooling curve indicate the first derivative of the recorded cooling curve. Therefore, the latent heat of solidification of the test sample can be written as:

$\mathrm{L}=\mathrm{C}_{\mathrm{P}} x$ (area between derived cooling curve and zero curve) 
Once the specific heat $\left(\mathrm{C}_{\mathrm{P}}\right)$ of the test sample material is known, the latent heat can be calculated from Equation 4. The solid fraction at time $t$ during solidification can be obtained by calculating the cumulative area between the first derivative curve $(C C)$ and the zero curve $\left(\mathrm{Z}_{\mathrm{N}}\right)$ as a fraction of total area between these two curves (Figure 1). The Newtonian method is convenient to use for the latent heat determination when only the specific heat $\mathrm{Cp}$, for example from DSC measurement, is known. Even this information is not necessary if one wants to know, for example, fraction solid dependence on the temperature or time, fs(T) or fs(t).

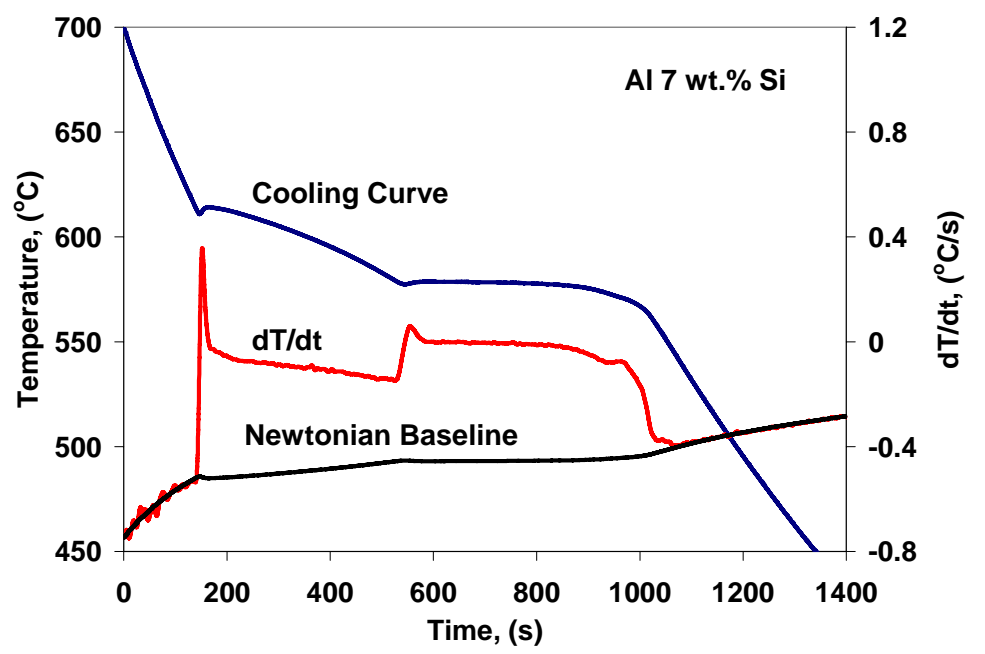

Figure 1 - Cooling curve, first derivative and Newtonian zero curve for $\mathrm{Al}-7 \%$ Si alloy

The only requirement necessary for accuracy in determination of the latent heat is that the thermal mass of the crucible used in the experiment should be as minimal as possible. In this case, the cooling process truly reflects the behaviour of the solidifying test sample and not the crucible -sample thermal system. In our experiment, the thermal mass of the crucible was less than $0.5 \%$ of the total thermal mass of the system.

\section{Fourier Analysis}

The Fourier analysis used in this study follows the method suggested by Fras et al [4]. This analysis considers the effect of thermal gradient during solidification and assumes that heat transfer takes place by conduction only. The Fourier equation with a heat source can be written as:

$$
\frac{\partial T}{\partial t}=\alpha \nabla^{2} T+\frac{1}{C_{V}} \frac{\partial Q}{\partial t}
$$


where, $\mathrm{C}_{\mathrm{v}}$ is the volumetric specific heat and $\alpha$ is the thermal diffusivity. Equation 5 can be written as [4]:

$$
\frac{\partial Q}{\partial t}=C_{V}\left(\frac{\partial T}{\partial t}-Z_{F}\right) \quad \text { where } Z_{F}=\alpha \nabla^{2} T
$$

where, $Z_{\mathrm{F}}$ is the Fourier zero curve. To calculate the zero curve, the temperature field in the test sample must be known. Considering a cylindrical mould, the $\nabla^{2} T$ can be calculated as [13]:

$$
\nabla^{2} T=\frac{1}{r} \frac{\partial}{\partial r}\left(r \frac{\partial T}{\partial t}\right)
$$

It is assumed in Eq. 7 that the process is axially symmetric and temperature is independent of $\theta$ coordinate. In treating this problem we express the temperature field in a parabolic form, i.e., $T=a r^{2}+b$. Considering a cylindrical mould with known temperatures at radii $R_{1}$ and $R_{2}$ in the test sample, $\nabla^{2} T$ can be calculated from Eq. 7 as follows:

$$
\nabla^{2} T=\frac{4\left(T_{2}-T_{1}\right)}{R_{2}^{2}-R_{1}^{2}}
$$

which is identical with form used by Fras et. al. [4].

In Eq. (8) $T_{1}$ and $T_{2}$ are temperatures at radii $R_{1}$ and $R_{2}$, respectively. The Fourier method of analysis considers the thermophysical properties of solid and liquid to be variable (time/temperature dependent). This is accomplished through an iterative procedure. First the thermal diffusivity before and after solidification is determined from experimental data according to the following equation:

$$
\alpha=\frac{\partial T / \partial t}{\nabla^{2} T}
$$

To start the iteration, solid fraction is assumed by a first order approximation to be:

$$
f_{s}=\frac{t-t_{s}}{t_{e}-t_{s}}
$$

where, $\mathrm{f}_{\mathrm{S}}$ is the fraction solid, and the subscripts $\mathrm{s}$ and e stand for the "start" and "end" of solidification determined from the first derivative curve. The thermophysical properties are calculated at each iterative step from: 


$$
\begin{aligned}
& \alpha(t)=\alpha_{i}\left[1-f_{S}(t)\right]+\alpha_{f} f_{S}(t) \\
& C_{V}(t)=C_{V l}\left[1-f_{S}(t)\right]+C_{V S} f_{S}(t)
\end{aligned}
$$

where, $\mathrm{C}_{\mathrm{VL}}$ and $\mathrm{C}_{\mathrm{VS}}$ are the volumetric specific heats of liquid and solid, respectively, $\alpha_{i}$ and $\alpha_{f}$ are the initial and final values of thermal diffusivity. The latent heat and the fraction solid can be calculated as $[2,4]$ :

$$
\begin{aligned}
& L=\int_{t_{S}}^{t_{e}}\left(\frac{\partial Q}{\partial t}\right)(t) d t \text { where } \frac{\partial Q}{\partial t}=C_{V}\left(\frac{\partial T}{\partial t}-Z_{F}\right) \\
& f_{S}(t)=\frac{1}{L} \int_{t_{S}}^{t}\left(\frac{\partial Q}{\partial t}\right)_{t}(t) d t
\end{aligned}
$$

The thermal diffusivity values are determined as a function of time from Equations 9 and 11. Then, Equations 6 and 11-14 can be used iteratively to calculate the Fourier zero curve. The rate of heat of solidification evolves and the volume fractions of solid phases can be estimated using Eq.14. The Fourier zero curve calculated from the cooling curve of $\mathrm{Al}-7 \% \mathrm{Si}$ alloy is shown in Figure 2, which shows that the first derivative and Fourier zero curves coincide before the onset of solidification and again once solidification is complete.

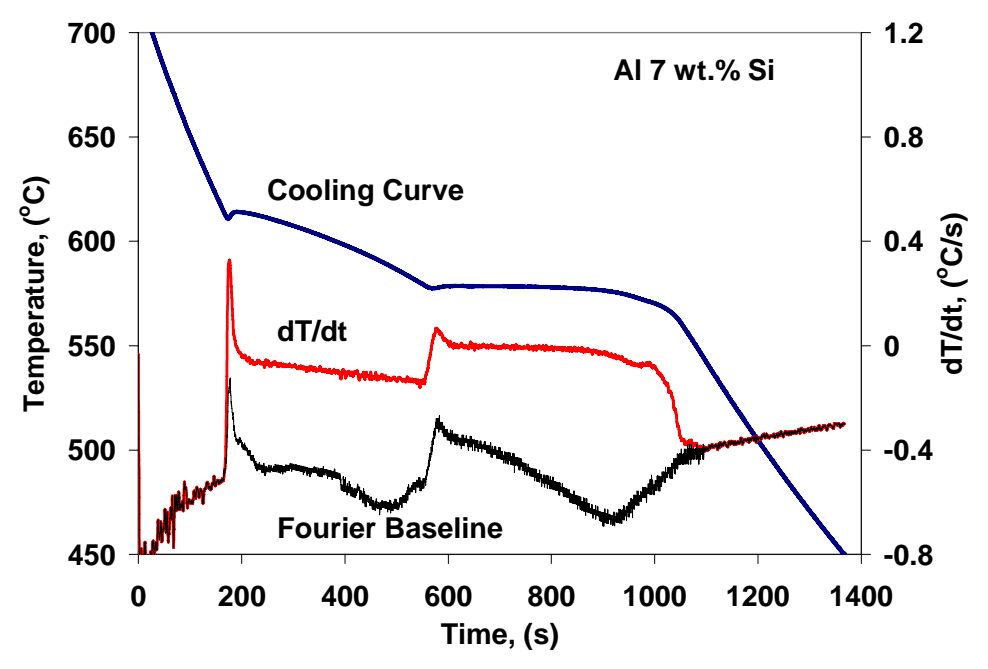

Figure 2 - Cooling curve for an Al - $7 \%$ Si alloy, its first derivativ and the Fourier zero curve 


\section{EXPERIMENTAL PROCEDURE}

Commercial 356 (Al-7wt.\% Si) aluminum alloy ingots were used in this study. The alloy was melted in a $12 \mathrm{~kg}$ capacity electric resistance furnace. During processing, the melt was covered with a protective nitrogen gas atmosphere to prevent hydrogen and oxygen contamination. No grain refining or silicon modification agents were added to the melt. The alloy chemistry is given in Table 1.

Table 1 - Average chemical composition of the 356 aluminum alloys

\begin{tabular}{|c|c|c|c|c|c|c|c|}
\hline Elements & $\mathrm{Si}$ & $\mathrm{Cu}$ & $\mathrm{Fe}$ & $\mathrm{Mg}$ & $\mathrm{Mn}$ & $\mathrm{Zn}$ & $\mathrm{Ti}$ \\
\hline Wt.\% & 7.0 & 0.01 & 0.34 & 0.33 & 0.21 & 0.01 & 0.01 \\
\hline
\end{tabular}

\section{Thermal Analysis Procedure}

Samples with masses of approximately $300 \mathrm{~g} \pm 10 \mathrm{~g}$ were poured into specially manufactured, ultra light, stainless steel (SS 304) cups, (mass $=2.5 \pm$ $0.2 \mathrm{~g}$ ). Two specially designed, supersensitive $\mathrm{K}$ type thermocouples (with extra low thermal time constants) were used to record sample temperature (between $750-400^{\circ} \mathrm{C}$ ). One thermocouple was located at the center and the second near the cup wall. Temperature readings were collected by a data acquisition system at a sampling rate of 5 per second. Two samples of each alloy were taken for the thermal analysis. The TA data was collected using a high-speed National Instruments data acquisition system linked to a personal computer. Each trial was repeated twice. The steel cup was insulated at the bottom and top in order to satisfy the assumptions made in solving Newtonian and Fourier equations.

After each experiment, the solidified samples were sectioned at the location of the thermocouples and their position in the sample was measured accurately. The cooling curve data was then processed by Newtonian and Fourier techniques. A computer program was developed to process the data and calculate the latent heat and fraction solid. The processing included smoothening, curve fitting, calculating of the first and second derivatives, identification of the start and end of solidification, calculating the zero curve, predicting the specific heat and density of the alloy during solidification, and calculating the latent heat and solid fraction using an iterative method. The cooling rate was calculated from the slope of the cooling curve of the liquid, i.e., above the liquidus temperature. The solidified samples were then cut, polished and etched for optical microscopy.

In order to evaluate the importance of the experimental procedure and the type of sampling cup, additional experiments were carried out using a graphite cup (samples with mass of $65 \mathrm{~g}$ of Al). The cup was immersed in the melt for approximately a minute to allow the cup temperature to equilibrate with the melt temperature. The cup, with $65 \mathrm{~g}$ of Al, was transferred to the cooling apparatus. Similar procedure with the steel cup samples was followed to analyze the cooling curves. 


\section{RESULTS AND DISCUSSION}

\section{Fourier and Newtonian Zero Curves}

The first step in analyzing the cooling curve is to compute the zero curve for that alloy. The cooling curve of an $\mathrm{Al}-7 \% \mathrm{Si}$ alloy solidified at a cooling rate of $0.55{ }^{\circ} \mathrm{C} / \mathrm{s}$ as well as the Newtonian and Fourier zero curves calculated from cooling curves are shown in Figures 1 and 2, respectively. The Newtonian "zero curve" in Figure 1 was determined by fitting the polynomial of $3^{\text {rd }}$ order to all data points (recorder cooling curve and its calculated $1^{\text {st }}$ derivative) before liquidus and after solidus states.

A comparison of Fourier and polynomial Newtonian zero curves and the areas between the first derivative and zero curve, which is proportional to the latent heat, are shown in Figure 3. Figure 3 shows a remarkable difference between the two zero curves. Because the Fourier analysis is based on the actual temperature field of the metal, it is expected to be more reliable in its predictions compared with the Newtonian method. The polynomial Newtonian zero curve may also be estimated with a line going through data points before liquidus and after solidus states (Figure 3). The area calculated by Fourier method is $8 \%$ larger, and from linear Newtonian is $3.6 \%$ lower than polynomial Newtonian curve.

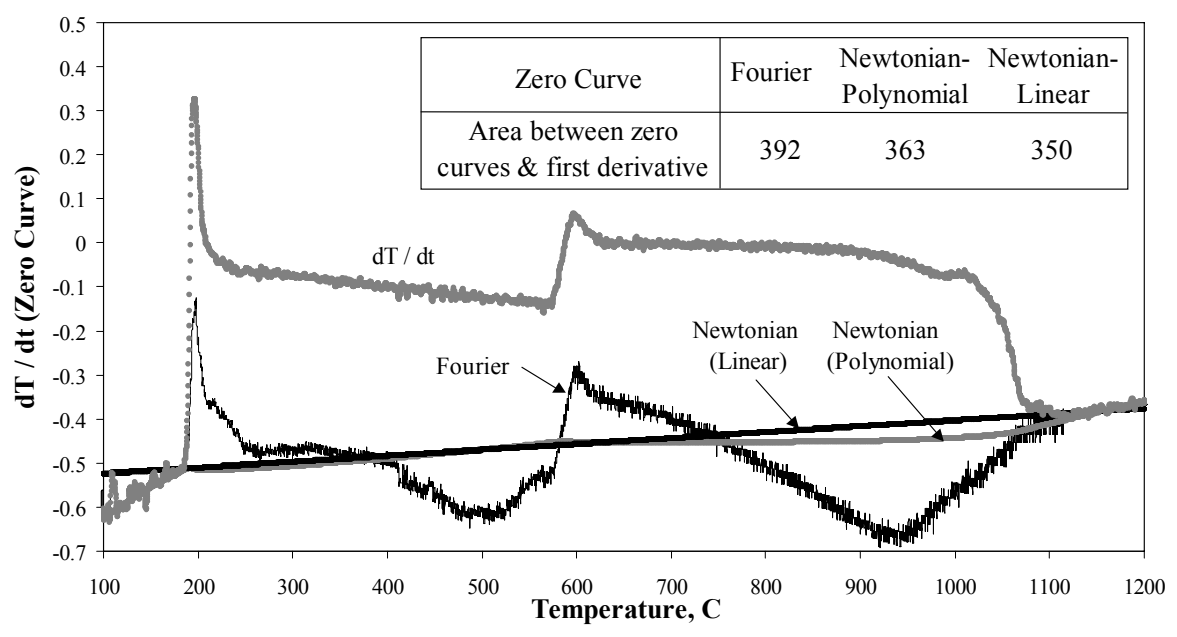

Figure 3 - Comparison of polynomial and linear Newtonian and Fourier zero curves for a 356 ( $\mathrm{Al}-7 \%$ Si) alloy

\section{Calculation of Latent Heat}

The calculated values of the latent heat by either Fourier or Newtonian methods were compared with the one measured by Differential Scanning Calorimetry (DSC) apparatus in order to verify their accuracy. As mentioned 
earlier, the difference between the first derivative of the cooling curve and the zero curve at any given time represents the heat of the metallurgical reactions generated within solidifying test sample at that point and therefore, fraction solid can be calculated at any temperature between the liquid and solid states.

In order to calculate the latent heat of solidification and fraction solid using equations (4) or (13), the sensible specific heat (average over solidification range) is needed for Newtonian method and in the case of Fourier method, both $\mathrm{Cp}$ and overall density will have to be known as a function of temperature during solidification. As the thermal analysis test sample is a mixture of solid and liquid phases during solidification, the composition and fraction of each phase change as the melt cools. Thus, it is important to calculate the specific heat of each changing phase during solidification. Bäckerud claimed the difference in specific heat of the solid and liquid is so small that an average value can be used [6]. The specific heat of binary Al-7 wt $\% \mathrm{Si}$ was calculated at several stages during solidification to estimate the effect of changes in volume fraction and composition of solid and liquid phases during solidification on the overall specific heat. The overall specific heat, $\mathrm{C}_{\mathrm{P}}$, at any moment during solidification, can be written as:

$$
C_{P}=f_{S} \cdot C_{P(\text { Solid) }}+\left(1-f_{S}\right) C_{P \text { (Liquid) }}
$$

where, $\mathrm{f}_{\mathrm{S}}$ is the solid fraction. The $\mathrm{C}_{\mathrm{P}}$ of pure solid and liquid aluminum are given in Equations 16 and 17 [13, 14]:

$$
\begin{aligned}
& C_{P} \mathrm{Al}\left(\text { solid) }=0.76617+0.46145 \times 10^{-3} \mathrm{~T}, \mathrm{~kJ} / \mathrm{kg} . \mathrm{K}\right. \\
& \text { for } T \leq 933.2^{\circ} \mathrm{K} \\
& C_{P} \mathrm{Al} \text { (liquid) }=1.086, \mathrm{~kJ} / \mathrm{kg} . \mathrm{K} \text { for } 933.2 \leq \mathrm{T}
\end{aligned}
$$

where $\mathrm{T}$ is the temperature in degree $\mathrm{K}$. The $\mathrm{C}_{\mathrm{P}}$ of binary Al-Si alloys in the solid state has been reported by Nageswar et al [17] as follows:

Binary Al-Si alloy: $C_{P}$ (solid) $=C_{P}(\mathrm{Al})\left(1-1.6 \times 10^{-3} \mathrm{wt} \% \mathrm{Si}\right), \mathrm{kJ} / \mathrm{kg} . \mathrm{K}$

Due to the lack of data on the specific heat of liquid Al-Si alloys, it is assumed that $\mathrm{Si}$ has the same effect on the $\mathrm{C}_{\mathrm{P}}$ of liquid and solid. Using Eqs. 15 to 18 , and extrapolating the literature data, the --specific heat of an $\mathrm{Al}-7 \% \mathrm{Si}$ alloy at the liquidus temperature $\left(\mathrm{T}_{\mathrm{L}}\right)$, slightly above $\left(\mathrm{T}_{\mathrm{E}}+\epsilon\right)$ and slightly below $\left(\mathrm{T}_{\mathrm{E}}-\epsilon\right)$ the eutectic temperature, were calculated (see Table 2).

Table 2 shows that during solidification the specific heat of the system increases from 1.074 to $1.143 \mathrm{~kJ} / \mathrm{kg} . \mathrm{K}$, i.e. an increase of $6.4 \%$. Therefore, taking an average value of $\mathrm{C}_{\mathrm{p}}$ could generate an error on latent heat calculation by about $3.2 \%$. 
Table 2 - Calculated values of specific heat of Al-7\%Si alloy at the liquidus temperature $\left(T_{L}\right)$, just above $\left(T_{E}+\epsilon\right)$ and below $\left(T_{E}-\epsilon\right)$ the eutectic temperature

\begin{tabular}{|c|c|c|c|c|c|}
\hline \multicolumn{6}{|c|}{$\begin{array}{c}\text { Alloy: A356 (Al-7\% } \% \text { Si), Cooling rate (in liquid) }=0.55{ }^{\circ} \mathrm{C} / \mathrm{s} \\
\mathrm{T}_{\mathrm{L}}=612.1{ }^{\circ} \mathrm{C}, \mathrm{T}_{\mathrm{E}}=577.6{ }^{\circ} \mathrm{C}\end{array}$} \\
\hline $\mathrm{T}\left({ }^{\circ} \mathrm{C}\right)$ & Phase & $\% \mathrm{Si}$ & $\begin{array}{l}\text { Vol. } \\
\text { Fraction }\end{array}$ & $\begin{array}{c}\mathrm{C}_{\mathrm{p}} \\
(\mathrm{kJ} / \mathrm{kg} . \mathrm{K})\end{array}$ & $\begin{array}{l}\mathrm{C}_{\mathrm{P}} \text { (system) } \\
\text { from Eq.14 }\end{array}$ \\
\hline $\mathrm{T}_{\mathrm{L}}$ & $\begin{array}{l}\mathrm{S}_{\alpha} \\
\mathrm{L}\end{array}$ & $\begin{array}{l}0 \\
7\end{array}$ & $\begin{array}{l}0 \\
1\end{array}$ & $\begin{array}{l}1.175 \\
1.074\end{array}$ & 1.074 \\
\hline $\mathrm{T}_{\mathrm{E}}+\epsilon$ & $\begin{array}{l}\mathrm{S}_{\alpha} \\
\mathrm{L}\end{array}$ & $\begin{array}{c}1.6 \\
11.7\end{array}$ & $\begin{array}{l}0.55 \\
0.45\end{array}$ & $\begin{array}{l}1.156 \\
1.066\end{array}$ & 1.116 \\
\hline $\mathrm{T}_{\mathrm{E}}-\epsilon$ & $\begin{array}{l}\mathrm{S}_{\alpha} \\
\mathrm{Si}\end{array}$ & $\begin{array}{c}1.6 \\
100\end{array}$ & $\begin{array}{l}0.947 \\
0.053\end{array}$ & $\begin{array}{l}1.156 \\
0.917\end{array}$ & 1.143 \\
\hline
\end{tabular}

The solid and liquid densities are also a function of temperature and $\mathrm{Si}$ content [18-20]. The density of the system increases from 2.43 to $2.68 \mathrm{~g} / \mathrm{cm}^{3}$ (i.e. an increase of 10\%) during solidification [12]. Therefore, in this study, the system's specific heat and density were calculated from the volume fraction and composition of the existing phases throughout the solidification.

In order to verify which method for calculating zero curves is more accurate, the calculated values of latent heat are compared with those measured by DSC apparatus. A review of the literature has shown a lack of data related to determination of the latent heat of solidification of the 3XX series aluminum alloys. Quested et al. [21] calculated the latent heat of the Al-6 wt\%Si-0.3 wt $\% \mathrm{Mg}$ alloy to be $425 \mathrm{~J} / \mathrm{g} \pm 5$. Tamminen in his Ph.D. thesis [22] also used the DSC apparatus to determine the latent heat contribution of the Si phase. Using his reported values and interpolating them to $7 \mathrm{wt} . \% \mathrm{Si}$, a latent heat value of $459 \mathrm{~J} / \mathrm{g}$ was calculated. Barlow and Stefanescu [2] evaluated latent heat for two aluminum alloys by using Fourier analysis. The value of latent heat for Al-6.55 wt.\% Si alloy was calculated to be $419 \mathrm{~J} / \mathrm{g}$, while for the Al-8.36 wt.\% Si alloy the value was $440 \mathrm{~J} / \mathrm{g}$. The latent heat of the A356 alloy (Al-7\% $\%$ i) measured by DSC (in this work) and calculated by Fourier and Newtonian methods (Figures 1 and 2) are given in Table 3 . The specific heat and density were calculated at every stage during solidification for calculation of latent heat and solid fraction.

Table 3 - Total latent heat calculated by Newtonian and Fourier methods, and measured by DSC

\begin{tabular}{|c|c|c|c|c|}
\hline \multirow{2}{*}{ Alloy } & \multicolumn{4}{|c|}{ Latent Heat, J/g } \\
\cline { 2 - 5 } & $\begin{array}{c}\text { Newtonian } \\
\text { Polynomial }\end{array}$ & $\begin{array}{c}\text { Newtonian } \\
\text { Linear }\end{array}$ & Fourier & DSC method \\
\hline A356 (Al-7\% $\%$ Si) & 403 & 387 & 435 & 432.20 \\
\hline
\end{tabular}


As can be seen in Table 3, the latent heat calculated by Fourier technique is almost the same as that measured by DSC. The latent heat calculated by polynomial and linear Newtonian methods are lower than DSC values by $6.8 \%$ and $10.5 \%$, respectively.

It should be mentioned that the calculated latent heat depends on the values of specific heat used in the calculations. Using an average specific heat value of $1.2 \mathrm{~J} / \mathrm{gk}[15,16]$, the latent heat calculated from Figure 3 for Fourier and Newtonian analysis are 470 and $436 \mathrm{~J} / \mathrm{g}$, respectively. In this case, the latent heat calculated by Newtonian method is closer to DSC than Fourier analysis. Both methods seem to be reliable techniques for latent heat determination, but it is difficult to determine which method is more accurate.

\section{Fraction of Solid}

A comparison of solidified volume fractions predicted by Newtonian and Fourier methods are given in Figure 4. This figure shows that there are small differences in the amount of fraction solid calculated using Fourier or Newtonian methods, especially in the temperature range between liquidus and $\mathrm{Al}-\mathrm{Si}$ eutectic temperature. Cooling further towards the solidus temperature these differences are getting less significant. The fractions of solid at eutectic temperature are compared with those measured by DSC in Table 5. It is seen that the predictions of the three methods are very close and within the range of experimental errors. Therefore, It is difficult to estimate which method is more accurate to be applied for calculation of the fraction solid based on limited number of experiments. Thus, additional experiments (Quenching during solidification) are needed to clarify the accuracy of the two techniques. The review of the literature data have also shown a significant difference in fraction of solid calculated from these two methods for an eutectic cast iron [5].

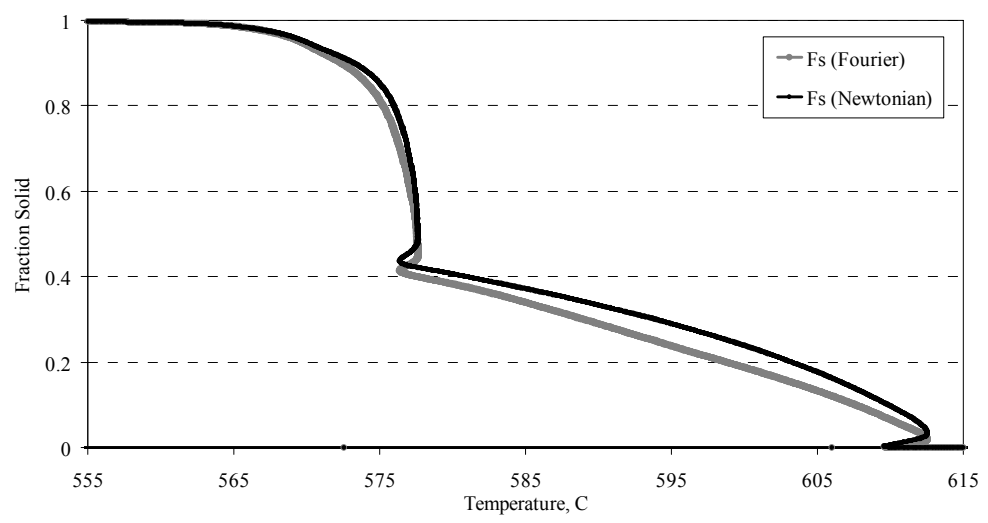

Figure 4 - Comparisons of solidified volume fractions calculated by Newtonian (polynomial) and Fourier methods for an Al - $7 \%$ Si alloy at a cooling rate of $0.55^{\circ} \mathrm{C} / \mathrm{s}$ 


\section{Type of Sampling Cup}

As mentioned earlier, a few experiments were carried out using a graphite cup to evaluate the importance of the experimental procedure and the type of sampling cup on the TA results. A comparison of Fourier and Newtonian zero curves and the area between the first derivative and zero curves, are shown in Figure 5. The area calculated by Fourier analysis for a graphite cup is lower than that obtained by steel cup, by about $8.9 \%$. However, the Newtonian results are significantly smaller than those measured by steel cup by more than $56 \%$.

The latent heat calculated by Fourier and Newtonian methods for the graphite cup are given in Table 4 . The specific heat and density were calculated at every stage during solidification for calculation of latent heat. The latent heats calculated by Fourier analysis are almost the same for a steel and graphite sampling cup. However, the latent heat calculated by Newtonian analysis for a graphite cup is significantly lower than for a steel cup by about $51 \%$. The difference in the values of the calculated latent heat by both methods can be explained by the following arguments. The Newtonian approach does require as minimal as possible thermal mass of the experimental crucible (as was stated before). In the experiments carried by use of the graphite cup, this condition was severely violated. The graphite cup mass, $65 \mathrm{~g}$, is about same as sample mass, which is the probable cause of inaccurate estimation of the evolved latent heat of solidification. Therefore, the Fourier technique is more reliable in its latent heat prediction than Newtonian technique and the calculations seem to be independent of the type of sampling cup and experimental procedure. This is due to the fact that Fourier analysis is based on the actual temperature field of the metal, which are measured by two thermocouples.

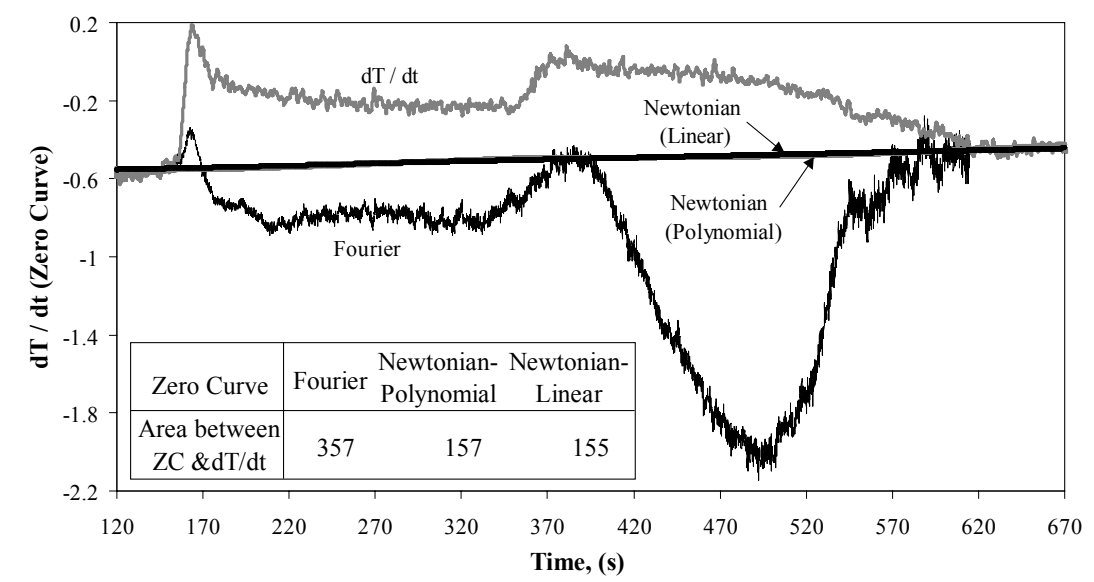

Figure 5 - Comparison of polynomial and linear Newtonian and Fourier zero curves for a 356 (Al - $7 \%$ Si) alloy using a graphite sampling cup 
Table 4 - Latent heat calculated by Newtonian and Fourier methods using a graphite sampling cup

\begin{tabular}{|c|c|c|c|c|}
\hline \multirow{2}{*}{ Alloy } & \multicolumn{4}{|c|}{ Latent Heat, J/g } \\
\cline { 2 - 5 } & $\begin{array}{c}\text { Newtonian } \\
\text { Polynomial }\end{array}$ & $\begin{array}{c}\text { Newtonian } \\
\text { Linear }\end{array}$ & Fourier & DSC method \\
\hline A356 (Al-7\%Si) & 172 & 170 & 394 & 432.20 \\
\hline
\end{tabular}

Table 5 - Fraction of solid at eutectic temperature (Alpha-Al\%)

\begin{tabular}{|c|c|c|c|}
\hline \multirow{2}{*}{ Alloy } & \multicolumn{3}{|c|}{ Latent Heat, J/g } \\
\cline { 2 - 4 } & $\begin{array}{c}\text { Newtonian } \\
\text { Polynomial }\end{array}$ & Fourier & DSC method \\
\hline A356 (Al-7\%Si) & 0.43 & 0.41 & 0.46 \\
\hline
\end{tabular}

\section{CONCLUSIONS}

The computer-aided cooling curve analysis (CA-CCA) method was used to calculate latent heat and solid fraction for Al-Si alloys. Newtonian and Fourier methods of zero curve calculations were presented. A comparison of the literature and computed latent heats for a steel sampling cup shows that both methods provide a fairly accurate means of determining the latent heat. However, the significant difference in the shape of zero curves is being reflected in the calculation of solid fraction and its dependence on the temperature or time.

Fourier technique is more reliable in its latent heat prediction than Newtonian technique and the calculations seem to be independent of the type of sampling cup and experimental procedure. This is due to the fact that Fourier analysis is based on the actual temperature field of the metal, which are measured by two thermocouples.

The Fourier calculations seem to be independent of the type of sampling cup, and therefore, it is more reliable in its latent heat prediction than Newtonian technique. The dependence of the two techniques to experimental procedure and type of sampling cup should be further analyzed.

Using the average values of specific heat and density affect the latent heat calculations and might add to the calculation's errors, therefore, it is recommended to calculate the specific heat and density of the system from the volume fraction and composition of the existing phases throughout the solidification. 


\section{ACKNOWLEDGEMENT}

The authors are grateful for financial support of the Canadian Lightweight Materials Research Initiatives (CLiMRI) and technical assistance of Mr. Peter Newcombe of MTL

\section{REFERENCES}

[1] Y.F. Chen, S.H. Jong and W.S. Hwang, "Effects of Cooling Rate on Latent Heat Released Mode of Pure Aluminum and Aluminum-Silicon Alloys", Metarials Science and Technology, Vol. 12, July 1996, 539-544

[2] J.O. Barlow and D.M. Stefanescu, "Computer-Aided Cooling Curve Analysis Revisited", AFS Transactions, Vol. 105, 1997, 349-354

[3] K.G. Upadhya, D.M. Stefanescu, K. Lieu and D.P. Yeager, "ComputerAided Cooling Curve Analysis: Principles and Applications in Metal Casting”, AFS Transactions, Vol. 97, 1989, 61-66

[4] E. Fras, W. Kapturkiewicz, A. Burbielko and H.F. Lopez, "A New Concept in Thermal Analysis of Castings", AFS Transactions, Vol. 101, 1993, 505511

[5] I.G. Chen and D.M. Stefanescu, "Computer-Aided Differential Thermal Analysis of Spheroidal and Compacted Graphite Cast Irons", AFS Transactions, Vol. 92, 1984, 947-963

[6] L. Bäckerud, G. Chai and J. Tamminen, Solidification Characteristics of Aluminum Alloys, Volume 2: Foundry Alloys, Amercan Foundrymen's Society Inc., Des Plaines, IL, 1990

[7] S. -C. Jeng and S. $-\mathrm{W}$. Chen, "Determination of the Solidification Characteristics of the A356.2 Aluminum Alloy", Materials Science Forum, Vols. 217-222, 1996, 283-288

[8] S. Gowri, "Comparison of Thermal Analysis Parameters of 356 and 359 Alloys", AFS Transactions, Vol. 102, 1994, 503-508 
[9] W.T. Kierkus and J. H. Sokolowski, "Recent Advances in CCA: A New Method of Determining 'Baseline' Equation", AFS Transactions, 1999, v. $66,161-167$.

[10] J.H. Sokolowski, M.B. Djurdjevic and R.I. Mackay, "Effect of Cooling Rate on the Fraction Solid of the Metallurgical Reactions in the 319 Alloy", AFS Transactions, Vol. 108, 2000,

[11] A.M. Figuerdo, Y. Sumartha and M.C. Flemings, "Measurements and Calculation of Solid Fraction in Quenched Semi-Solid Melts of Rheocast Aluminum Alloy A357”, Light Metals, 1998, 1103-1106.

[12] D. Emadi and L. Whiting; "Determination of Solidification Characteristics of Al-Si Alloys by Thermal Analysis", AFS Transactions, Vol. 110, 2002, 285-296.

[13] S. Whitaker, Fundamental Principles of Heat Transfer, Pergamon Press Inc., Don Mills, Ontario, 1977, 1-51

[14] R.D. Pehlke, A. Jeyarajan and H. Wada, Summary of Thermal Properties for Casting Alloys and Mold Materials, University of Michigan, Ann Arbor, Michigan, USA, 1982

[15] J. B. Henderson and A. Strobel, "Measurements of the Thermophysical Properties of Molten Metal Alloys", NETZSCH Applications Laboratory Thermophysical Properties Section, March 1995.

[16] J. B. Henderson and J. Blumm and L. Hagemann, "Measurements of the Thermophysical

[17] Properties of Aluminum-Silicon Casting Alloy in the Solid and the Molten Regions", NETZSCH Applications Laboratory Thermophysical Properties Section, June 1996.

[18] Y. Nageswar and N.M. Murthy, "Heat Capacity Measurement Technique and Studies on Aluminum-Silicon alloys", Indian Journal of Pure and Applied Physics, Vol. 29, No. 3, March 1991, 223-225

[19]E.A. Brandes and G.B. Brook, Smithells Metals Reference book, $2^{\text {nd }}$ edition, Butteworth-heinemann ltd., Linacre House, Oxford, England, 1992

[20] D. Emadi, "Porosity Formation in Sr-Modified Al-Si Alloys", Ph. D. Thesis, McGill University, Montreal, Canada, May 1995, 59-77 
[21] J.D. Edwards, 'Thermal properties of Aluminum-Silicon Alloys”,Chemical and Metallurgical Eng., Vol. 28, No. 4, 1923, 165-169

[22]P. N Quested, K. C. Mills, R.F. Brooks, B. Monaghan, A. T. Dinsdale, A. Day, M. J. Richardson, R. J. L. Andon, R. Taylor and H. Szelagowski, “ Physical Property Measurements for the Mathematical Modelling of Heat and Fluid Flow in Solidification Processess", Proceedings of the $7^{\text {th }}$ Conference "Modelling of Casting, Welding and Advanced Solidification Processes" 1995, Edited by M. Cross and J. Campbell, TMS Warrendale, Pennsylvania, USA.

[23] J. Tamminen, "Thermal Analysis for Investigation of Solidification Mechanisms in Metals and Alloys", Doctoral Dissertation, S-106, 91 Stockholm, Sweden, 1998. 